ISSN: $2338-4794$

Vol.6. No. 3 Sept.- Des. 2018

\title{
PENGARUH RETURN ON ASSETS DAN CURRENT RATIO TERHADAP HARGA SAHAM PERUSAHAAN PT. ULTRA JAYA MILK.Tbk
}

\author{
Eneng Rochmah ${ }^{1}$ ) \\ 1) Mahasiswa Program Studi Manajemen FE UNKRIS \\ Herry Winarto ${ }^{2}$ ) \\ 2) Dosen Program Studi Manajemen FE UNKRIS \\ Alamat: Kampus UNKRIS, Jatiwaringin Jakarta Timur \\ Email : herrywinarto45@Yahoo.Com
}

\begin{abstract}
This research was conducted to describe the Return on Assets (ROA) and Current ratio (CR) of PT Ultra jaya mil Tbk's stock prices partially and simultaneously. The research method in this study uses simple regression analysis techniques, multiple regression, assumption test, test $F$ and $T$. test simultaneously obtained that Return On Assets and Current Ratio to Investment Prices and Returns on Assets Against Stock Prices have a positive and significant effect
\end{abstract}

Keywords: Asset returns, current assets, stock prices.

\section{PENDAHULUAN}

Jumlah penduduk Indonesia yang terus bertambah dengan adanya Usaha Mikro Kesil Menengah (UMKM) yang makin berkembang pesat membuat potensi pertumbuhan kebutuhan terhadap layanan makanan dan minuman di Indonesia menjadi semakin meningkat. Jumlah penduduk yang terus meningkat menimbulkan permintaan yang tinggi terhadap industri makanan dan minumnan yang lebih baik. Pertumbuhan industri food and beverage di Indonesia semakin pesat. Industri food and beverage bisa mendapatkan peluang yang lebih besar untuk terus berkembang. Pertumbuhan food and beverage sebesar 8,4\% di 2016 dimana pertumbuhan ini diatas pertumbuhan ekonomi yang sebesar $5,02 \%$. Pertumbuhan ini merupakan pertumbuhan positif. Industri food and beverage juga memiliki daya saing cukup kuat. Selain itu, pemain industri ini juga beragam, tidak ada pelaku yang mendominisasi. "Gabungan Pengusaha Makanan dan Minuman seluruh
Indonesia memproyeksi, pertumbuhan industri food and beverage bakal mengalami stagnan pada tahun 2017, pertumbuhan industri food and beverage tahun ini masih bisa sama dengan tahun lalu yakni sekitar 8,4\%" (GAPMI, 2017). Karena maka dari itu, kementrian perindustran sepakat mau merevisi proyeksi bisnis industri food and beverage 2017.

Pemasoknya tidak terganggu ,mulai bahan baku, produksi, sampai ke konsumen. Karena dari pada itu kementrian perindustrian mendorong "sektor dari industri food and beverage ini bisa menjadi alat pemeratan mengingat banyak industri kecil dan menengah disektor ini yang didaerahpun hidup" (Endarwati, 2017). Peluang untuk menanamkan investasi pada sektor food and beverage ini sangat menjanjikan, karena pasar masih terbuka lebar dengan jumlah penduduk yang besar pula. Pertumbuhan ekonomi dan jumlah penduduk Indonesia yang besar menjadi penopang pertumbuhan pendapatan ini. Omzet penjualan industri food and 
beverage domestik bisa tetap naik sekitar 8\% - 9\% menjadi Rp 756 trilun - Rp 763 triliun dibandingkan omzet penjualan makanan di 2012 yang berkisar Rp 700 triliun. Menurut (kemenperin, 2016) "Pasar food and beverage terus bertumbuh konsisten".

Berawal dari sebuah perusahaan susu di tahun 1950-an, PT Ultrajaya telah berkembang dengan sangat pesat hingga mampu meraih posisi saat ini sebagaisalah satu perusahaan terkemuka di Indonesia untuk produk-produk susu dan jus buah.Kisah PT Ultrajaya diawali dari sebuah perusahaan susu yang kecil padatahun 1958. Lalu pada tahun 1971, perusahaan ini memasuki tahap pertumbuhan pesat sejalan dengan perubahannya menjadi PT Ultrajaya Milk Industry \& Trading Company. PT Ultrajaya saat ini merupakan perusahaan pertama dan terbesar diIndonesia yang menghasilkan produkproduk susu, minuman dan makanan dalamkemasan aseptik yang tahan lama dengan merek-merek terkenal seperti Ultra Milk untuk produk susu, Buavita untuk jus buah segar dan Teh Kotak untuk minuman teh segar.

Suatu perusahaan diharapkan dapat terus berkembang. Sementara pengembangan tersebut membutuhkan modal. Modal itu sendiri menjadi salah satu aspek penting dalam perusahaan baik dalam pembukuan bisnis maupun pengembangannya. Oleh karena itu, perusahaan harus menentukan seberapa banyak modal yang diperlukan untuk membiayai perusahaan. Dana dari dalam perusahaan yaitu melalui laba ditahan dan depresiasi serta dana dari luar peusahaan yaitu dana yang berasal dari kreditur dan investor atau para pemegang saham. "Pasar modal merupakan lembaga perantara antara pihak memiliki kelebihan dana dengan pihak yang sedang membutuhkan dana, dan sebagai lembaga yang mendorong terciptanya alokasi dana yang efisien" (Tandelilin,
2010). "Pasar modal yang sering diperdagangkan adalah saham. Saham adalah tanda bukti keikutseraan sebagai pemilik dalam suatu perusahaan" (Riyanto, 2011).

Nilai perusahaan yang tinggi akan dapat memaksimalkan kekayaan pemegang saham. Jika harga saham tinggi, maka nilai perusahaan tersebut akan tinggi pula dan dapat kepercayaan para investor pada perusahaan yang mengeluarkan saham tersebut (Wiagustini, 2010). Salah satu surat berharga yang dikategorikan efek dan diperdagangkan dipasar modal adalah saham (Darmadji, 2011) saham adalah tanda penyertaan atau bukti pemilikan seseorang atau badan dalam suatu perusahaan. Harga saham dipasar modal Indonesia memiliki kecenderungan yang fluktuatif dan berubah-ubah setiap detiknya.

Saham itu sendiri merupakan suatu modal dasar sebelum terjun kedalam dunia investasi perusahaan. Jika membeli saham berarti membeli sebagian kepemilikan atas perusahaan tersebut, dan berhak atas keuntungan dari perusahaan dalam bentuk deviden. Di pasar modal yang diperjual belikan terhadap harga pasar. Harga pasar saham ialah harga yang ditentukan oleh investor melalui pertemuan permintaan dan penawaran. Pertemuan dapat terjadi jika para investor setuju terhadap harga saham tersebut. menurut Zuliarni (2012) itu sendiri ialah "harga saham adalah salah satu indikator keberhasilan pengelolaan perusahaan, jikalau harga saham suatu perusahaan selalu mengalami kenaikan, maka investor dan calon investor menilai jika perusahaan berhasil dalam mengatur usahanya".

Tujuan utama berinvestasi ialah agar mendapatkan pengembalian (return). Pengembalian (return) hasil dari hasil berinvestasi. Perusahaan yang akan membagikan keuntungan (deviden) tentu sudah memperhitungkan laba yang telah 
diperoleh, akan disimpan sebagai laba ditahan untuk ekspansi perusahaan atau dibagikan ke pemegang saham sebagai deviden, dan sedangkan capital gain ditentukan oleh fluktasi harga saham. Maka dari itu harga saham merupakan harga yang terjadi dipasar modal pada waktu tertentu yang dilakukan oleh pelaku pasar, yaitu permintaan dan penawaran.

Investor membutuhkan informasi yang tepat dan akurat tentang kinerja suatu perusahaan. Untuk mengetahui baik buruknya kinerja suatu perusahaan dapat dilakukan dengan cara analisis terhadap laporan keuangan perusahaan tersebut. Dalam penelitian ini alat analisis yang digunakan untuk meneliti harga saham adalah rasio keuangan. Rasio keuangan merupakan suatu alat analisa yang digunakan oleh perusahaan untuk menilai kinerja keuangan berdasarkan data perbandingan masing-masing pada periode tertentu. Rasio keuangan merupakan salah satu faktor fundamental yang digunakan sebagai acuan oleh seorang seorang investor yang akan menanamkan saham. Penelitian ini menggunakan variabel rasio keuangan, yaitu current ratio dan return on assets. Dimana variabel berkaitan dengan harga saham pada perusahaan food and beverage yang terdaftar di Bursa Efek Indonesia periode 2012-2017.

\section{LANDASAAN TEORI}

\section{Pasar Modal}

Pasar Modal dipandang sebagai salah satu saran efektif untuk mempercepat pembangunan suatu negara. Hal ini dimungkinkan karena pasar modal merupakan wahana yang dapat menggalang pengerahan dana jangka panjang dari masyarakat untuk disalurkan kesektor-sektor produktif. Apabila pengerahaan dana masyarakat melalui lembaga-lembaga keuangan maupun pasar modal sudah dapat berjalan dengan baik, maka dana pembangunan yang besumber dari luar negeri makin lama makin dikurangi. Dalam usaha peningkatan modal perusahaan dengan menarik dana dari luar perusahaan akan memperhatikan masalah jumlah dana dan jangka waktu untuk memperolehnya. Disamping iu, jenis dana yang ditarik tidak kalah penting pula untuk dipertimbangkan. Apakah dana yang ditarik itu pinjaman atau modal sendiri, akan tergantung pada posisi keuangan perusahaan yang telah ada. Jika perusahan sudah tidak mungkin untuk meningkatkan modal pinjaman, padahal peningkatan modal sudah sangat mendesak, akan semakin menyulitkan perusahaan, pemerintah berusaha menyediakan berbagai alternatif sumber dana yang dapat dimanfaatkan oleh perusahaan sesuai dengan kebutuhan dan posisinya.

Menurut Jogiyanto (2016) "Pasar modal adalah salah satu alternatif yang dapat dimanfaatkan perusahaan untuk memenuhui kebutuhan untuk memenuhi kebutuhan dananya". Perusahaan yang membutuhkan dana dapat menjual surat berharganya dipasar modal. Surat berharga yang baru dikeluarkan oleh perusahaan dijual dipasar primer (primary market), surat berharga yang baru dijual dapat berupa penawaran perdana ke publik atau tambahan surat berharga baru jika perusahaan sudah going public.

Menurut Husnan (2015) Secara formal "pasar modal dapat didefinisikan sebagai pasar untuk berbagai instrumen keuangan jangka panjang yang bisa diperjual belikan, maupun dalam bentuk hutang dan modal sendiri" dengan demikian pasar modal merupakan konsep yang lebih sempti dari pasar keuangan. Dalam pasar keuangan diperdagangkan semua bentuk hutang dan modal sendiri, baik dana jangka pendek ataupun jangka panjang. 
Selanjutnya surat berharga yang sudah beredar diperdagangkan dipasar sekunder. Perkembangan terakhir pasar modal memperlihatkan bahwa para pemodal itu kebanyakan terdiri dari pengelola dana (fund manager) dari dana pensiun, kepentingan mereka ikut campur tangan didalam kepengurusan perusahaan yng sahamnya mereka beli melalui pasar modal menjadi semakin tidak berarti.

Dipasar modal terdapat 3 istilah, yaitu : a). Pasar Perdana; Yang dimaksud pasar perdana adalah penjualan perdana efek/sertifikat penjualan yang dilakukan sesaat sebelum perdagangan dibursa/pasar sekunder. Pada pasar ini sertifikat diperdagangkan dengan harga emisi. Pada pasar perdana perusahaan akan memperoleh dana dengan menjual sekuritas (saham, obligasi, dan hipotek). Selanjutnya perusahaan dapat menggunakan dana hasil emisi tersebut untuk menambah barang modal dan seterusnya digunakan untuk memperoduksi barang dan jasa. Asrtinya pasar perdana ini sangat penting untuk pertumbuhan ekonomi. b). Pasar Sekunder; Yang dimaksud dengan pasar sekunder adalah penjualan efek/sertifikat setelah pasar perdana berakhir. Pada pasar ini efek diperdagangkan dengan harga kurs. Pasar sekunder merupakan pasar dimana surat berharga dijual setelah pasar perdana. Ditinjau dari sudut investor, pasar suekunder harus dapat menjamin likuiditas dari efek, artinya investor menghendaki dapat membeli kembali sekuritas jika ia mempunyai dan dan juga menghendaki menjual sekuritas untuk memperoleh uang tunai atau dapat mengalihkan kepada investor lain. c). Bursa Paralel; Sebenarnya yang dimaksud dengan bursa paralel ialah yang ketentuan-ketentuan dari "Paket Desember 1987) PAKDES yang menerbitkan 13 macam surat keputusan dan surat edaran yang berhubungan dengan pasar modal dan secara resmi mulai menyebutkan bursa paralel, masih belum ditemukan istilah tersebut. sedangkan kalu memperhatikan ketentuan-ketentuan yang diambil dari Pakdes, dapat disimpulkan bahwa bursa paralel adalah "suatu sistem perdagangan efek yang terorganisasi diluar Bursa Efek Indonesia, dengan bentuk pasar sekunder, diatur dan diselenggarakan dengan perserikatan perdagangan uang dan efekefek (PPUE), diawasi dan dibina oleh badan pelaksana pasar modal (Bapepam).

\section{Harga Saham}

Harga saham merupakan harga penutupan pasar saham periode pengamatan untuk tiap-tiap jenis saham yang dijadikan sample dan pergerakannya senantiasa diamati oleh para investor. Salah satu konsep dasar dalam manajemen keuangan adalah bahwa tujuan yang ingin dicapai manajemen keuangan adalah memaksimalkan nilai perusahaan. "Harga saham adalah harga suatu saham yang terjadi dipasar bursa pada saat tertentu yang ditentukan oleh pelaku dasar dan ditentukan oleh permintaan dan penawaran saham yang bersangkutan dipasar modal", Jogiyanto (2008).

Suatu perusahaan dapat menjual hak kepemilikannya dalam bentuk saham (stock). Jika perusahaan hanya mengeluarkan satu kelas saham saja, saham ini disebut dengan saham biasa (common stock). Menurut Aziz, Nadir, juga Mintarti (2015) " saham dapat diartikan sebagai bukti penyertaan bisa juga sebagai kepemilikan investor individual ataupu investor institusional (trader) atas investasi yang sudah diinvestasikan alam suatu perusahaan".

Untuk menarik investor potesial lainnya, suatu perusahaan mungkin juga mengeluarkan kelas lain dari saham, yaitu yang disebutkan dengan saham preferen (preferred stock). Saham preferen mempunyai hak-hak prioritas lebih dari saham biasa. Hak-hak prioritas dari saham preferen yaitu hak atas dividen 
yang tetap dan hak terhadap aktiva jika terjadi likuidasi. Akan tetapi, saham preferen umumnya tidak memiliki hak veto seperti yang dimiliki oleh saham biasa.

Saham preferen mempunyai sifat gabungan (hybrid) antara obligasi dan saham biasa. Seperti obligasi yang membayarkan bunga atas pinjaman, saham preferen juga memberikan hasil yang tetap berupa dividen preferen. Seperti saham biasa, dalam hal likuidasi, klaim pemegang saham preferen dibawah klaim pemegang saham obligasi. Dibandingkan dengan saham biasa, saham preferen mempunyai beberapa hak, yaitu hak atas dividen tetap dan hak pembayaran terlebih dahulu jika terjadi likuidasi. Oleh karena itu, saham preferen dianggap mempunyai karakteristik diengah-tengah antara obligasi dan saham biasa.

Saham biasa di suatu perusahaan hanya mengeluarkan satu kelas saham saja, saham ini biasanya dalam bentuk saham biasa (common stock). Pemegang saham adalah pemilik dari perusahaan yang mewakilkan kepada manajemen untuk menjalankan operasi perusahaan. Sebagai pemilik perusahan, pemegang saham biasa mempunyai bebrapa hak. Beberapa hak yang dimiliki oleh pemegang sahan biasa adalah hak kontrol, hak menerima pembagian keuntungan, hak preemptif, dan hak klaim sisa.

Manfaat kepemilikan saham untuk para investor ialah yang melakukan pembelian saham, otomatis akan memiliki hak kepemilikan didalam perusahaan yang menertibkannya. Banyak sedikitnya jumlah saham yang dibeli akan menentukan persentase kepemilikan dari investor tersebut. yang menjadi pertanyaan sekarang adalah apakah keuntungan yang akan didapat oleh seseorang jika melakukan pembelian saham. Secara umum, ada dua manfaat yang bisa diperoleh bagi pembeli saham, yaitu manfaat ekonomis dan manfaat non ekonomis. Manfaaat ekonomis meliputi perolehan dividen dan perolehan capital gain. Dividen merupakan sebagian keuntungan perusahaan yang dibagikan kepada pemegang saham, sedangkan capital gain adalah keuntungan yang diperoleh investor dari hasil jual beli saham, berupa selisih antara nilai jual yang lebih tinggi dibandingkan nilai beli yang lebih rendah. Manfaat nonekonomis yang bisa diperoleh oleh pemegang saham adalah kepemilikan hak suara dalam Rapat Umum Pemegang Saham (RPUS) untuk menentukan jalannya perusahaan.

\section{Laporan Keuangan}

Laporan keuangan (financial statements) merupakan produk akhir dari serangkaian proses pemcatatan dan pengikhtisaran data transaksi bisnis. Seorang diharapkan mampu untuk mengorganisir seluruh data keuangan hingga mengahsilkan laporan keuangan dan bahkan harus dapat menginterprestasikan serta menganalisa laporan keuangan yang dibuatnya. laporan keuangan pada dasarnya adalah "hasil dari proses data keuangan yang dapat digunakan sebagai alat untuk berkomunikasi dalam aktivitas perusahaan kepada pihak - pihak yang berkepentingan", Hery (2017).

Dengan kata lain, laporan keuangan ini berfungsi sebagai alat informasi yang menghubungkan perusahaan dengan pihak - pihak yang berkepentingan, yang menunjukan kondisi kesehatan keuangan perusahaan dan kinerja perusahaan. Urutan laporan keuangan berdasarkan proses penyajiannya adalah sebagai berikut : 1). Neraca; Neraca adalah sebuah laporan yang sistematis tentang posisi aset, kewajiban, dan ekuitas perusahaan per tanggal tertentu. Tujuan dari laporan ini tidak lain adalah untuk menggambarkan posisi keuangan perusahaan. 2). Laporan Laba Rugi; 
Laporan laba rugi merupakan laporan yang sistematis tentang pendapatan dan beban perusahaan untuk satu periode waktu tertentu. Laporan laba rugi ini pada akhirnya memuat informasi mengenai hasil kinerja manajemen atau hasil kegiatan operasional perusahaan, yaitu laba atau rugi bersih yang merupakan hasil dari pendapatan dan keuntungan dikurangi dengan beban dan kerugian. 3). Lapoaran Perubahaan Modal; Laporan perubahaan modal adalah sebuah laporan yang menyajikan ikhtisar perubahaan dalam ekuitas pemilik suatu perusahaan untuk satu periode waktu tertentu. 4). Laporan Arus Kas; Laporan arus kas adalah sebuah laporan yang menggambarkan arus kas masuk dan arus kas keluar secara terpirinci dari masingmasing aktivitas, yaitu mulai dari aktivitas operasi, aktivitas investasi, sampai pada aktivitas pendanaan/ pembiayaan untuk satu periode waktu tertentu. Laporan arus kas menunjukan besarnya kenaikan/penurunan bersih kas dari seluruh aktivitas selama periode berjalan serta saldo kas yang dimiliki perusahaan sampai dengan periode.

\section{Kinerja Keuangan}

Kinerja keuangan pada dasarnya merupakan penilaian mengenai hasil keuangan yang diukur pada suatu periode tertentu, apakah mengalami kemajuan ataupun sebaliknya. Penilaian ini biasanya dibandingkan antara satu periode dengan periode lainnya. Mengevaluasi kinerja keuangan merupakan kegiatan yang wajib dilakukan perusahaan untuk menilai hasil keuangan.

Menurut Rudianto

berpendapat bahwa pengertian kinerja keuangan adalah : "Hasil atau prestasi yang telah dicapai oleh manajemen perusahaan dalam menjalankan fungsinya mengelola asset perusahaan secara efektif selama periode tertentu"
Menurut Fahmi (2012) "kinerja keuangan merupakan cerminan tentang keberhasilan perusahaan berupa hasil yang telah dicapai karena kegiatan yang telah dilakukan, kinerja keuangan juga mampu mengetahui sejauh mana perusahaan melakukan kegiatan sesuai aturan yang terdapat di keuangan"

Kinerja keuangan bersangkutan dengan pengukuran dan penilaian kinerja perusahaan, untuk mengevaluasi kinerja keuangan suatu perusahaan hal yang dapat dilakukan adalah menganalisa kinerja keuangan. Dengan menggunakan alat analisis laporan keuangan, terutama bagi pemilik usaha dan manajemen,dapat diketahaui berbagai hal yang berkaitan dengan keuangan dan kemajuan perusahaan. Alat yang sering digunakan selama pemeriksaan adalah rasio keuangan.

\section{Rasio Proditabilitas}

Rasio profitabilitas merupakan rasio yang digunakan untuk mengukur kemampuan perusahaan dalam menghasilkan laba dari aktivitas normal bisnisnya. Tujuan operasional dari sebagian besar perusahaan adalah untuk memaksimalisasi profit, baik profit jangka pendek maupun profit jangka panjang. Manajemen dituntut untuk meningkatkan imbal hasil (return) bagi pemilik perusahaan. Rasio profitabilitas tidak hanya berguna bagi perusahaan saja, melainkan juga bagi pihak luar perusahaan. Dalam praktiknya, ada banyak manfaat yang dapat diperoleh dari rasio profitabilitas, baik bagi pihak pemilik perusahaan, manajemen perusahaan, maupun para pemangku kepentingan lainnya yang terkait dengan perusahaan.

Profitabilitas merupakan salah satu indikator yang digunakan untuk mengukur kinerja keuangan perusahaan. Rasio profitabilitas terdiri dari dua jenis, yaitu rasio yang menujukan profitabilitas dalam kaitannya dengan penjualan dan 
rasio yang menunjukan profitabilitas dalam kaitannya dengan investasi. Profitabilitas yang berkaitan dengan investasi salah satunya dalam penelitian ini menggunakan rasio Return On Assets. Return On Assets merupakan rasio profitabilitas yang digunakan untuk mengukur efektivitas perusahaan didalam keuntungan dngan memanfaatkan total aktiva yang dimilikinya. Salah satu jenis rasio profitabilitas ialah Return On Assets yang merupakan rasio seberapa besar kontribusi aset dalam menciptakan laba bersih. Dengan kata lain, rasio ini digunakan untuk mengukur seberapa besar jumlah laba bersih yang akan dihasilkan dari setiap rupiah dana yang tertanam dalam total aset.

Menurut Hery (2017) "Return on assets merupakan rasio yang menunjukan hasil atas penggunaan aset perusahaan dalam menciptakan laba bersih". Dengan kata lain, rasio ini digunakan untuk mengukur seberapa besar jumlah laba bersih yang akan dihasilkan dari setiap rupiah dana yang tertanam dalam total asset.

Menurut Kasmir (2012) "Return On Assets (ROA) adalah rasio yang menunjukan hasil (return) atas jumlah aktiva yang biasa digunakan dalam suatu perusahaan"

Menurut Houston (2011) "Teori signaling menjelaskan suatu tindakan yang diambil manajemen perusahaan yang memberi petunjuk bagi para investor tentang bagaimana manajemen memandang perusahaan"

Selain itu, Return On Assets memberikan nilai yang lebih baik atas profitabilitas perusahaan karena menunjukan efektivitas manajemen dalam menggunakan aktiva untuk meperoleh suatu pendapatan pada perusahaan. Semakin besar Return On Asset menunjukan kinerja perusahaan semakin baik, karena return semakin besar. Return On Asset digunakan untuk mengukur efektifitas perusahaan didalam menghasilkan keuntungan dengan memanfaatkan aktiva yang dimilikinya. Rasio ini merupakan rasio yang terpenting diantara dari rasio profitabilitas yang lainnya. Return On Asset diperoleh dari membandingkan $\mathrm{Net}$ Income After Tax dengan total asset. Semakin besar Return On Assets menunjukkan kinerja yang semakin baik, karena tingkat pengembalian semakin besar. Dengan tingginya Return On Assets kepada para investor untuk membeli saham tersebut.

Berikut rumus yang digunakan untuk menghitung hasil pengembalian atas aset :

$$
R O A=\frac{\text { laba bersih }}{\text { total aset }} \times 100 \%
$$

\section{Rasio Likuiditas}

Rasio likuiditas merupakan suatu indikator mengenai kemampuan perusahaan-perusahaan membayar semua kewajiban finansial jangka pendek pada jatuh tempo dengan menggunkan aktiva lancar yang tersedia. Likuiditas tidak hanya berkenan dengan keadaan keseluruhan keuangan perusahaan, tetapi juga berkaitan dengan kemampuannya mengubah aktiva lancar tertentu menjadi uang kas. Rasio likuiditas merupakan rasio yang menunjukan atau mengukur kemampuan perusahaan dalam memenuhi kewajibannya yang sudah jatuh tempo, baik kewajiban luar perusahaan, maupun didalam perusahaan.

Suatu perusahaan yang mempunyai alat-alat likuid sedemikian besarnya sehingga mampu memenuhi segala kewajiban financialnya yang segera harus terpenuhi, dikatakan bahwa perusahaan tersebut likuid, dan sebaliknya apabila perusahaan tidak mempunyai alat-alat likuid yang cukup untuk memenuhi segala kewajiban financial yang segera harus terpenuhi dikatakan perusahaan tersebut insolvable. Likuiditas merupakan suatu indikator mengenai kemampuan perusahaan-perusahaan membayar semua 
kewajiban financial jangka pendek pada saat jatuh tempo dengan menggunakan aktiva lancar yang tersedia. Likuiditas tidak hanya berkenan dengan keadaan keseluruhan keuangan perusahaan, tetapi juga berkaitan dengan kemampuannya mengubah aktiva lancar tertentu menjadi modal.

Jenis rasio likuiditas salah satunya adalah current ratio (CR) yang merupakan perbandingan antara aktiva lancar dan kewajiban lancar dan merupakan ukuran yang paling umum digunakan untuk memenuhi kewajiban jangka pendeknya. Current ratio (CR) merupakan perbandingan antara aktiva lancar dan kewajiban lancar yang merupakan ukuran paling umum digunakan untuk mengetahui kesanggupan suatu perusahaan memenuhi jangka pendeknya.

Menuru Kasmir (2012). "Jenis rasio likuiditas salah satu adalah Current Ratio yang merupakan perbandingan antara aktiva lancar dan kewajiban lancar dan merupakan ukuran yang paling umum digunakan untuk mengetahui kesanggupan suatu perusahaan memenuhi kewaiban jangka pendek."

Menurut Fahmi (2012) "Rasio likuiditas merupakan rasio yang menunjukan atau mengukur kemampuan perusahaan dalam memenuhi kewajiban kepada luar perusahaan maupun dalam perusahaan."

Menurut Hery, (2017) "Current ratio merupakan rasio untuk mengukur kemampuan perusahaan dalam memenuhi kewajiban jangka pendeknya yang akan segera jatuh tempo dengan menggunakan aset lancar yang tersedia."

Menurut Sawir (2013) "Current ratio yang rendah biasanya dianggap menunjukan terjadinya masalah dalam likuidasi, sebaliknya Current Ratio yang terlalu tinggi juga kurang bagus, karena menunjukan banyaknya dana menganggur yang pada akhirnya dapat mengurangi kemampuan perusahaan.”
Current ratio menunjukan sejauh mana aktiva lancar menutupi kewajibankewajiban lancar. Semakin besar perbandingan aktiva lancar dan kewajiban lancar semakin tinggi kemampuan perusahaan menutupi kewajiban jangka pendeknya. Apabila mengukur tingkat likuiditas dengan menggunakan current ratio sebagai alat pengukurnya, makan tingkat atau current ratio sebagai alat pengukurnya, maka tingkat likuiditas atau current ratio suatu perusahaan dapat dipertinggi dengan cara : a). Dengan hutang lancar tertentu, diusahakan untuk menambah aktiva lancar. b). Dengan aktiva lancar tertentu, diusahakan untuk mengurangi jumlah hutang lancar. c). Dengan mengurangi jumlah hutang lancar sama-sama dengan mengurangi aktiva lancar.

Berikut rumus yang digunakan untuk menghitung Current Ratio :

$$
C R=\frac{\text { aktiva lancar }}{\text { hutang lancar }} \times 100 \%
$$

\section{METODE PENELITIAN}

Metode pengumpulan data yang dilakukan melalui penelitian kepustakaan dan pengambilan data sekunder, yaitu sumber data penelitian yang diperoleh secara tidak langsung melalui media perantara laporan keuangan dan harga saham dari tahun 2012 sampai dengan tahun 2017 yang terdapat dalam IDX Quarterly yang dikeluarkan oleh Bursa Efek Indonesia.

Penelitian ini menggunakan metode kuantitatif dengan melakukan analisis kinerja keuangan dan pergerakan harga saham pada perusahaan Food and Beverage yang terdapat pada BEI periode $2012 \quad-2017$ (www.idx.co.id). Selanjutnya dilakukan uji model menggunakan analisis regresi, koefisien determinasi dan uji hipotesis 


\section{HASIL PENELITIAN}

Analisis data dilakukan dengan cara yakni regresi linier berganda. Data yang tersedia bagi variabel dependen yaitu harga saham dan variabel independen yang terdiri dari return on assets dan current ratio. Analisis dilakukan dengan menguji pengaruh kedua variabel independen terhadap variabel dependen harga saham perusahaan secara simultan melalui uji statistik $\mathrm{F}$ dan secara parsial melalui uji statistik t.

\section{Pengaruh Return On Assets dan Current Ratio secara simultan terhadap Harga Saham \\ Untuk mengetahui bagaimana} pengaruh Return On Assets dan Current ratio terhadap harga saham secara simultan, maka penulis melakukan pengujian regresi berganda, dengan hasil sebagai berikut :

Persamaan regresi berganda secara simultan untuk penelitian ini adalah sebagai berikut :

$$
Y=2,875+0,072 X_{1}-0,016 X_{2}
$$

Persamaan regresi secara simultan yang di peroleh dapat di simpulkan sebagai berikut : a). Bisa diartikan hasil regresi berganda secara simultan, menunjukan nilai konstanta sebesar 2,875 . Dapat diartikan bahwa pada saat Return On assets dan Current Ratio tidak mengalami perubahaan atau pada konstan (bernilai 0) maka Harga Saham positif 2,875. b). Bisa diartikan hasil regresi berganda secara simultan dari tabel 1 , menunjukan nilai koefisien regresi Return On Assets sebesar 0,072. Hal ini berarti bahwa setiap terjadi kenaikan 1 untuk Return On Assets akan diikuti kenaikan harga saham 0,072 dan begitu pula sebaliknya. 3). Bisa diartikan hasil regresi berganda secara simultan, menunjukan nilai koefisien regresi current ratio sebesar -0,016. Hal ini berarti bahwa setiap terjadi kenaikan 1 untuk current ratio akan diikuti kenaikan harga saham 0,016 dan begitu pula sebaliknya.

Dapat dilihat nilai sig (signifikansi) sebesar 0,000 lebih kecil dari tingkat deviasi sebesar 0,05 artinya ada pengaruh signifikan antara return on assets dan current ratio terhadap harga saham. Uji ini juga dapat dilihat dari perbandingan $F_{\text {hitung }}$ dengan $F_{\text {tabel. }}$. Dimana jika $F_{\text {hitung }}>$ $\mathrm{F}_{\text {tabel }}$, maka Ha ditolak dan H0 diterima atau Return On Assets dan Current Ratio berpengaruh signifikan terhadap harga saham. Sebaliknya, apabila $\mathrm{F}_{\text {hitung }}<\mathrm{F}_{\text {tabel }}$ maka Ha ditolak dan $\mathrm{H} 0$ diterima atau return on assets dan current ratio tidak berpengaruh signifikan terhadap harga saham. Pada tabel 1, menunjukan hasil uji statistik $\mathrm{F}$ dengan nilai $F_{\text {hitung }}>\mathrm{F}_{\text {tabel }}$ yaitu sebesar 19,623>3,328. Maka dapat disimpulkan bahwa Ha ditolak dan $\mathrm{H} 0$ diterima, dan artinya terdapat pengaruh simultan yang signifikan antara Return On Assets dan Current Ratio terhadap Harga Saham pada tingkat $a=0,05$.

Nilai koefisien determinasi atau $\mathrm{R}$ Square $\left(\mathrm{R}^{2}\right)$ diperoleh sebesar 0,575 menunjukan nilai kontribusi Return On Assets dan Current Ratio terhadap variabel Harga Saham namun jika dalam bentuk persen adalah $57,5 \%$ sisanya sebesar $42,5 \%$ yang dipengaruhi oleh variabel lainnya yang tidak dimasukan dalam penenlitian ini.

\section{Pengaruh Return On Assets secara parsial terhadap Harga Saham}

Untuk mengetahui bagaimana pengaruh return on assets terhadap harga saham secara parsial maka penulis melakukan pengujian regresi sederhana, dengan hasil sebagai berikut : 
Persamaan regresi secara parsial untuk penelitian ini adalah sebagai berikut :

$$
\mathrm{Y}=\mathbf{2 , 8 6 0}+\mathbf{0 , 0 5 0 \mathrm { X } _ { 1 }}
$$

Persamaan regresi secara parsial yang diperoleh dapat disimpulkant sebagai berikut: a). Bisa diartikan hasil regresi secara parsial dari tabel 2, menunjukan nilai konstanta sebesar 2,860. Dapat diartikan bahwa pada saat return on assets tidak mengalami perubahaan atau pada kondisi konstan (bernilai 0) maka harga saham positif 2,860. b). Bisa diartikan hasil regresi sederhana secara parsial dari tabel 2 , nilai koefisien regresi return on assets sebesar 0,067 . Hal ini berarti bahwa setiap terjadi kenaikan 1 satuan untuk Return On Assets akan diikuti kenaikan Harga Saham sebesar 0,067 dan begitu pula sebaliknya.

Dapat dilihat nilai signifikansi sebesar 0,000 lebih kecil dari tingkat deviasi sebesar 0,05 artinya ada pengaruh sgnifikan return on assets terhadap harga saham. Dengan kata lain return on assets ini secara parsial berpengaruh terhadap Harga Saham. Uji ini juga dapat dilihat dari perbandingan $t_{\text {hitung }}$ dan $t_{\text {tabel }}$ dimana jika $t_{\text {hitung }}>\mathrm{t}$ tabel maka Ha diterima atau secara parsial Return On Assets berpengaruh terhadap Harga Saham. Sebaliknya $t_{\text {hitung }}<$ tabel H0 diterima atau Return On Assets tidak signifikan terhadap Harga saham. Uji ini juga dapat dilihat dari perbandingan tabel dengan thitung sebesar 6,344 > 2,040. Maka Ho ditolak yang berarti Return On Assets berpengaruh signifikan terhadap Harga Saham pada tingkat $a=0,05$.

Nilai koefisien determinasi atau $\mathrm{R}$ Square $\left(\mathrm{R}^{2}\right)$ diperoleh sebesar 0,573 menunjukan nlai kontribusi Return On Assets terhadap Harga Saham namun jika dalam bentuk persen adalah 57,3\% sisanya sebesar $42,7 \%$ yang disumbangkan oleh variabel lainnya yang tidak dimasukan dalam penelitian ini.

\section{Pengaruh Current Ratio (CR) secara parsial terhadap Harga Saham}

Untuk mengetahui bagaimana pengaruh Current Ratio terhadap Harga Saham secara parsial maka penulis melakukan pengujian regresi, dengan hasil berikut :

Persamaan regresi linier sederhana untuk penelitian ini adalah sebagai berikut :

$$
\mathrm{Y}=\mathbf{2 , 9 8 4}+\mathbf{0 , 0 5 0 \mathrm { X } _ { 2 }}
$$

Persamaan regresi secara parsial yang diperoleh dapat disimpulkan sebagai berikut : a). Bisa diartikan hasil regresi secara parsial dari tabel 3. menunjukan nilai konstanta sebesar 2,984. Dapat diartikan bahwa pada saaat Current Ratio tidak mengalami perubahaan atau pada kondisi konstan (bernilai 0) maka Harga Saham positif 2,984. b). Bisa diartikan hasil regresi secara parsial dari tabel 3, nilai koefisien regresei current ratio sebesar 0,122. Hal ini berarti bahwa setiap terjadi kenaikan 1 untuk return on assets akan diikuti kenaikan Harga Saham sebesar 0,122 dan begitu pula sebaliknya.

Dapat dilihat nilai signifikansi sebesar 0,002 lebih kecil dari tingkat deviasi 0,05 artinya ada pengaruh signifikan current ratio terhadap Harga Saham dengan kata lain current ratio ini secara parsial berpengaruh terhadap Harga Saham. Uji ini juga dapat dilihat dari perbandingan $t_{\text {hitung }}$ dan $t_{\text {tabel }}$ dimana jika jika thitung $>t_{\text {tabel }}$ maka Ha diterima atau Current Ratio berpengaruh terhadap Harga Saham. Sebaliknya jika thitung < $\mathrm{t}_{\text {tabel }} \mathrm{HO}$ diterima atau Current Ratio tidak berpengaruh signifikan terhadap Harga Saham.

Hasil Uji $t_{\text {tabel }}$ dengan $t_{\text {hitung }}$ sebesar 3,387 > 2,040, maka H0 ditolak yang berarti Current Ratio berpengaruh signifikan terhadap Harga Saham pada tingkat $a=0,05$.

Nilai koefisien deteminasi atau $\mathrm{R}$ Square $\left(\mathrm{R}^{2}\right)$ diperoleh sebesar 0,277 menunjukan nilai kontribusi Current 
Ratio terhadap Harga Saham namun jika dalam bentuk persen adalah 27,7\% sisanya sebesar $72,3 \%$ yang disumbangkan oleh variabel lainnya yang tidak dimasukandalam penelitian ini.

\section{PEMBAHASAN}

Pembahasan didalam penelitian ini menggunakan dua variabel indenpenden yaitu Return On Assets dan Current Ratio sedangkan variabel dependen nya yaitu Harga Saham. Berdasarkan hasil penelitian ini yang menguji pengaruh antara Return On assets dan Current Ratio terhadap Harga Saham, maka akan dijelaskan beberapa hal di dalam penelitian ini yaitu sebagai berikut ;

\section{Pembahasan Return On Assets dan Current Ratio terhadap Harga Saham PT. UltraJaya Milk Tbk}

Berdasarkan pengujian yang sudah dilakukan dapat diperoleh suatu hasil bahwa Return On Assets dan Current Ratio berpengaruh signifikan terhadap harga saham

Naik turunnya Harga Saham dipasar modal menjadi suatu kejadian yang memang akan terjadi pada semua sektor industri. Hasil yang diperoleh dai penelitian ini dapat diartikan bahwa rasio keuangan sangat penting untuk menilai suatu perusahaan berdasarkan laporan keuangan yang diumumkan sebelum melakukan keputusan untuk membeli suatu saham. Jika dilihat dari perusahaan dengan hasil yang diperoleh bida dikatakan bahwa PT. UltraJaya Milk Tbk memperhatikan keadaan rasio keuangan yang ada, sehingga apabila rasio keuangan mengalami peningkatan akan mempengaruhi pergerakan harga saham yang mengalami kenaikan. Karena harga saham dapat tercemin dari nilai perusahaan, semakin baik nilai perusahaan semakin tinggi pula harga saham yang berarti semakin tinggi tingkat pengembalian kepada investor.

\section{Pembahasan Return On Assets terhadap Harga Saham PT. UltraJaya Milk Tbk}

Berdasarkan pengujian yang sudah dilakukan dapat diperoleh suatu hasil bahwa Return On Assets berpengaruh signifikan terhadap harga saham.

Hasil penelitian ini mendukung penelitian terdahulu yang dilakukan oleh Mujiono, yang menyatakan bahwa Return On Assets secara parsial juga memiliki pengaruh terhadap Harga Saham. Dari hasil yang diperoleh hal ini menyatakan bahwa manajemen perusahaan berhasil meningkatkan nilai perusahaan bagi pemilik perusahaan yang sesuai dengan tujuan manajemen keuangan dalam meningkatkan harga saham. Untuk itu perusahaan harus mempertahankan kegiatan yang dijalankan perusahaan agar lebih produktif, sehingga pemegang saham akan merasakan keuntungan yang lebih besar dari biaya modalnya.

\section{Pembahasan Current Ratio terhadap Harga Saham PT. UltraJaya Milk Tbk}

Berdasarkan pengujian yang sudah dilakukan dapat diperoleh suatu hasil bahwa Current Ratio terhadap harga saham.

Hasil penelitian ini tidak mendukung penelitian terdahulu yang dilakukan oleh Flodi Medial ( Univesitas Dian Nuswanto, Semarang 2016 ) dan Lena Antareka Universitas Muhammadiyah, Surakarta 2016), yang menyatakan bahwa Current Ratio tidak berpengaruh terhadap harga saham. Dari hasil yang diperoleh hal ini menyatakan bahwa perusahaan mampu dalam melunasi hutang - hutangnya.

Current Ratio merupakan rasio dimana para krditor mengukur operasi perusahaan dengan melihat apakah aktiva lancar perusahaan dapat memenuhi kewajiban jangka pendeknya saat jatuh tempo, karena semakin tinggi Current Ratio berarti semakin besar kemampuan 
perusahaan dalam melunasi hutang hutangnya. Maka dari pada itu para kreditur pun dapat mempertimbangkan untuk memberikan pinjaman bagi perusahaan. Tapi untuk para investor Current Ratio tidak memiliki pengaruh dikarenakan investor hanya melihat pada kegiatan usaha perusahaan tanpa melihat likuiditas perusahan.

\section{KESIMPULAN DAN SARAN}

\section{Kesimpulan}

Return on assets dan current ratio berpengaruh terhadap harga saham pada PT. UltraJaya Milk Tbk. 2). Return on assets berpengaruh terhadap Harga Saham pada PT. UltraJaya Milk Tbk. Dari hasil yang diperoleh hal ini menyatakan bahwa manajemen perusahaan berhasil meningkatkan nilai perusahaan bagi pemilik perusahaan yang sesuai dengan tujuan manajemen keuangan dalam meningkatkan harga saham. 3). Current ratio berpengaruh terhadap harga saham PT. UltraJaya Milk Tbk.

\section{Saran}

Berdasarkan kesimpulan dan keterbatasan yang ada pada penelitian ini. Maka dapat disampaikan beberapa saran sebagain berikut : 1). Jika ingin melakukan keputusan untuk membeli suatu saham diharapkan para investor harap memperhatikan rasio keuangan. Karena rasio keuangan sangat penting untuk menilai suatu perusahaan berdasarkan laporan keuangan. Dengan hasil penelitian ini bahwa Return On Assets dan Current Ratio mempunyai pengaruh yang positif dan signifikan terhadap Harga Saham pada PT. UltraJaya Milk Tbk, penulis menyarankan supaya perusahaan mempertahankan dan juga meningkatkan kinerja perusahaan yang terdapat pada PT. UltraJaya Milk Tbk baik manajemen hingga karyawannya. Karena bila kedua variabel tersebut terus meningkat maka harga saham juga akan meningkat sehingga para investor akan makin tertarik membeli saham pada perusahaan PT. UltraJaya Milk Tbk. 2). Berdasarkan penelitian ini Return On Assets berpengaruh positif dan signifikan terhadap Harga Saham pada PT. UltraJaya Milk Tbk, hal ini yang menandakan bahwa manajemen perusahaan berhasil meningkatkan nilai perusahaan bagi pemilik perusahaan yang sesuai dengan tujuan manajemen keuangan dalam meningkatkan harga saham. Hal ini dapat dijadikan sebagai indikasi preferensi para investor dan prlu juga memperhatikan sebelum melakukan investasi, untuk itu penulis menyarankan agar PT. UltraJaya Milk Tbk mempertahan hasil pengemblian aset agar menciptakan kontribusi yang besar pada laba bersih. 3). Berdasarkan penelitian ini Current Ratio berpengaruh positif dan signifikan terhadap Harga Saham pada PT. UltraJaya Milk Tbk, hal ini membuktikan juga bahwa para investor bisa melihat dari sisi fundamental perusahaan dalam mengambil keputusan untuk membeli Saham pada perusahaan PT. UltraJaya Milk Tbk. Perusahaan yang meningkatkan hutang bisa dipandang sebagain perusahaan yang yakin dengan pandangan perusahaan dimasa yang akan datang, sehingga diharapkan investor melihat sinyal positif dari perusahaan. Maka dari itu penulis menyarankan agar tetap mempertahankan aktiva lancar perusahaan terhadap hutang lancar perusahaan

\section{DAFTAR PUSTAKA}

Kurniawan. E,R , Rina Arifati, dan Rita Andini. 2016 .Pengaruh Cash Position, Debt Equity Ratio, Return On Assets, Current Ratio, Firm Size, Price Earning Ratio, dan Total Assets Turn Over terhadap Deviden Payout Ratio pada 
perusahaan Manufaktur periode 2007-20014. Universitas Padjajaran

Fitri Linda Rahmawati. 2009. Pengaruh Current Ratio, Invemtory Turnover, dan Debt To Equity Ratio terhadap Return On Assets (study pada perusahaan Food and Beverage yang Listing diBEI tahun 20072009).

Gapmi. "Pertumbuhan industri makanan dan minuman" 28 Juli 2017. http://www.gapmmi.or.id/

Hery, 2017. Analisis Laporan Keuangan. Jakarta : PT. GRASINDO.

Ina Rianti. 2008. Pengaruh Net Profit Margin (NPM), Return On Assets (ROA) dan Return On Equity (ROE) terhadap harga saham pada perusahaan yang tercantum dalam indeks LQ45. Universitas Gunadarma.

Kasmir 2010. Pengantar Manajemen Keuangan. Jakarta : Prenada Media Group.

Kementerian perindustrian." Perkembangan food and beverage" 16 Juni 2016. http://pameranln.kemenperin.go.id/ food-and-beveragel

Made Satria Wiradharma dan Luh Komang Sudjarni. 2016. Pengaruh tingkat Suku Bunga, tingkat Inflasi, Nilai Kurs Rupiah dan Produk Domestik Bruto terhadap Return saham. Universitas Udayana.
Munawir Adeputra dan Indra Wijaya. 2012. Pengaruh Nilai Tukar, Net Profit Margin, Return On Assets, Suku Bunga dan Inflasi terhadap Return saham Food and Beverage. Institut Teknologi dan Bisnis KALBIS

Oktiani Endarwati. "Prospek Industri Makanan dan Minuman dalam Negeri Cerah". 7 Febuari 2017. https://ekbis.sindonews.com/read/1 177763/34/prospek-industrimakanan-dan-minuman-dalamnegeri-cerah-1486460879

Pandji Anoraga dan piji pakarti, 2006. Pengantar Pasar Moda. Jakarta : Rineka Cipta

Mustafa. 2017. Manajemen Keuangan. Yogyakarta : CV. Andi Offset .

Jogiyanto Hartono. 2015. Teori Portofolio dan Analisis Investasi. Yogyakarta : BPFE YOGYAKARTA

Reynard Valintino dan Lana Sularto. 2013. Pengaruh Return On Assets Current Ratio, Return On Equity, Debt To Equity Ratio, dan Earning Per Share terhadap harga saham perusahaan manufaktur sektor industri barang konsumsi di BEI. Universitas Gunadarma

www.idx.com 